\title{
PENGARUH LIKUIDITAS, KEPUTUSAN PENDANAAN, DAN KINERJA PERUSAHAAN TERHADAP NILAI PERUSAHAAN YANG DIMODERASI GOOD CORPORATE GOVERNANCE \\ (STUDI EMPIRIS PADA PERUSAHAAN PROPERTY, REAL ESTATE, DAN BUILDING CONSTRUCTION DI BURSA EFEK INDONESIA)
}

\section{THE EFFECT OF LIQUIDITY, FUNDING DECISION, AND FIRM PEFORMANCE ON FIRM VALUE MODERATED BY GOOD CORPORATE GOVERNANCE (AN EMPIRICAL STUDY OF PROPERTY, REAL ESTATE, AND BUILDING CONSTRUCTION COMPANIES IN INDONESIA STOCK EXCHANGE)}

\author{
Hendrianto ${ }^{1}$, Yulia Efni², Andewi Rokhmawati ${ }^{3}$ \\ 1,2,3 Universitas Riau; Pekanbaru \\ hendrianto1.hh@gmail.com
}

\begin{abstract}
ABSTRAK
Penelitian ini bertujuan untuk menganalisis pengaruh dari likuiditas, keputusan pendanaan, dan kinerja perusahaan terhadap nilai perusahaan pada sektor property, real estate, dan building construction yang terdaftar di Bursa Efek Indonesia dari tahun 2015 hingga 2017. Serta menganalisis bagaimana penerapan good corporate governance dalam melakukan fungsi pengawasan terhadap manajemen. Metode penarikan sampel menggunakan purposive sampling dan diperoleh 44 perusahaan property, real estate, dan building construction yang menjadi sampel. Alat analisis data yang digunakan adalah partial least square (PLS). Hasil dari penelitian ini menunjukkan bahwa likuiditas dan good corporate governance tidak berpengaruh terhadap nilai perusahaan. Berbeda dengan keputusan pendanaan dan kinerja perusahaan yang berpengaruh signifikan terhadap nilai perusahaan. Likuiditas berpengaruh terhadap nilai perusahaan melalui kinerja perusahaan. Keputusan pendanaan berpengaruh terhadap nilai perusahaan melalui kinerja perusahaan. Good corporate governance tidak memoderasi hubungan likuiditas terhadap nilai perusahaan. Good corporate governance tidak memoderasi hubungan kinerja perusahaan terhadap nilai perusahaan. Good corporate governance tidak memoderasi hubungan keputusan pendanaan terhadap nilai perusahaan.
\end{abstract}

Kata Kunci : Nilai Perusahaan, Kinerja Perusahaan, GCG, Likuiditas, Pendanaan

\begin{abstract}
This research aims to analyze the impact of liquidity, funding decision, and firm performance on firm value of the property, real estate, and building construction sector that are listed on the Indonesia Stock Exchange from 2015 to 2017. This study also proposes to analyze the implementation of good corporate governance in overseeing and managing a corporation's business. Forty-four companies of property, real estate and building construction are obtained as research samples using the purposive sampling method and the data are analyzed using partial least square (PLS). The result shows that liquidity and good corporate governance does not affect the firm value. However, funding decision and firm performance does. On the other hand, liquidity has an effect on firm value through the performance of the company; and funding decision affects firm value through the firm performance. Based on the results, good corporate governance cannot moderate the relationship of liquidity and firm value. It also cannot moderate the relationship of firm performance and firm value as well as the relationship of funding decision and firm value.
\end{abstract}

Keywords : Firm Value, Firm Performance, GCG, Corporate, Liquidity, Funding Decision. 


\section{PENDAHULUAN}

Pertumbuhan indeks sektor property, real estate, dan building construction dari tahun 2015 sampai 2017 hanya mengalami kenaikan sekitar 0.81\%, sebaliknya indek harga saham gabungan atau IHSG tumbuh sekitar $38.36 \%$ pada periode yang sama (Data BEI 2015-2017). Hal ini menunjukkan bahwa nilai perusahaan disektor ini masih belum beranjak naik dari 4 tahun belakangan. Pembangunan infrastruktur dan kebijakan kebijakan ekonomi pemerintah seperti pertama menaikkan batas pajak penjualan atas barang mewah (PPnBM) untuk hunian mewah dan apartemen (Peraturan Menteri Keuangan (PMK) Nomor 106/PMK.010/2015), kedua membolehkan warga asing memiliki properti di dalam negeri (tertuang dalam Permen ATR/Kepala Badan Pertanahan Nasional Nomor 13 Tahun 2016). Serta program tax amnesti pada bulan Juli 2016 silam. Kebijakan-kebijakan pemerintah tersebut belum mampu untuk meningkatkan nilai perusahaan di sektor sektor property, real estate, dan building construction.

Memaksimalkan nilai perusahaan sangat penting bagi suatu perusahaan, memaksimalkan nilai perusahaan berarti juga memaksimalkan kemakmuran pemegang saham yang merupakan tujuan perusahaan (Hanafi,2016). Nilai perusahaan akan tercermin dari harga sahamnya (Fama, 1978). Semakin tinggi harga saham semakin tinggi pula nilai perusahaan. Beberapa hasil penelitian tentang nilai perusahaan menunjukkan hasil yang beragam (Putri, et al, 2016; Prasetyorini, 2013; Mardiyati, et al, 2012; Safitri, et al, 2014; Hamidy, et al 2015; Laksitaputri 2012), mereka menemukan bahwa profitabilitas berpengaruh signifikan terhadap nilai perusahaan. Didukung oleh penelitian Hidayati (2008) yang menemukan bahwa return on equity berpengaruh signifikan dan positif terhadap price book value. Sedangkan penelitian Kusuma et al (2012) menunjukkan hasil yang berbeda, bahwa profitabilitas tidak memiliki pengaruh signifikan terhadap nilai perusahaan. Diperkuat oleh penelitian Sudiyatno et al (2012) menyatakan bahwa ROA berpengaruh negatif terhadap nilai perusahaan.

Likuiditas merupakan salah satu faktor yang menentukan sukses atau kegagalan perusahaan. Secara umum pengertian likuiditas mengacu pada kemampuan perusahaan untuk memenuhi kewajiban jangka pendeknya (Kasmir, 2014). Kasmir (2014) berpendapat bahwa likuiditas adalah kemampuan perusahaan dalam memenuhi kewajiban (utang) jangka pendek. Likuiditas yang tinggi akan menguntungkan perusahaan, karena resiko perusahaan menjadi rendah, tetapi profitabilitas perusahaan akan menurun (Hanafi, 2016).

Selain kebijakan jangka pendek, keputusan pendanaan merupakan sangat penting dan berpengaruh terhadap kinerja dan nilai perusahaan. Menurut teori trade off, pendanaan melalui utang akan meningkatkan nilai perusahaan sampai pada batas tertentu, yaitu biaya pinjaman lebih besar dari pada biaya penghematan pajak (Hanafi, 2016). Hasil studi empiris menunjukkan hasil yang beragam, Hidayat (2008) menyatakan bahwa DER berpengaruh negatif dan tidak signifikan terhadap PBV, sedangkan Chowdhury dan Chowdhury (2010) menyatakan bahwa DER berpengaruh signifikan terhadap nilai perusahaan.

\section{LANDASAN TEORI}

Sebagaimana yang kita ketahui bahwa tujuan perusahaan adalah memaksimalkan kekayaan pemegang saham, yang diartikan memaksimalkan harga saham, namun sudah diketahui sejak lama bahwa manajer perusahaan mempunyai tujuan sendiri yang tidak jarang bertentangan dengan tujuan memaksimumkan pemegang saham. Faktanya manajemen perusahaan diberikan kekuasaan oleh pemegang saham untuk mengambil keputusan yang dapat 
menciptakan konflik kepentingan yang disebut dengan teori agensi atau agency theory ( Wiyono dan Kusuma, 2017).

Menurut Van Horne dalam (Rodoni, 2014) yang dimaksud dengan nilai perusahaan. " Value is represented by the market price of the company's common stock which in turn, is afunction of firm's investment, financing and dividend decision". Harga saham merupakan parameter kinerja perusahaan. Nillai perusahaan merupakan persepsi investor terhadap perusahaan, yang sering dikaitkan dengan harga saham, harga saham yang tinggi membuat nilai perusahaan juga tinggi (Wiyono dan Kusuma, 2017). Kinerja merupakan gambaran dari pencapaian pelaksanaan suatu kegiatan dalam mewujudkan tujuan perusahaan. Untuk meningkatkan kinerja perusahaan para manajer melakukan beberapa kebijakan internal seperti kebijakan pendanaan, kebijakan modal kerja, kebijakan-kebijakan yang dibuat manajer akan berpengaruh terhadap kinerja dan nilai perusahaan.

Likuiditas yang dimaksud dalam penelitian ini adalah manajemen modal kerja, menurut Sartono (2010) manajemen modal kerja berelasi terhadap keputusan investasi pada aktiva lancar dan utang lancar terutama mengenai bagaimana menggunakan dan komposisi keduanya akan mempengaruhi resiko. Modal kerja diperlukan perusahaan untuk membiayai kegiatan operasional perusahaan. Manajemen moda yang efektif menjadi sangat penting untuk pertumbuhan kelangsungan perusahaan dalam jangka panjang. Perusahaan yang tidak memiliki modal kerja yang cukup, tidak dapat membayar kewajiban jangka pendek tepat pada waktunya dan akan menghadapi masalah likuiditas.

Keputusan pendanaan menurut Husnan dan Pudjiastuti (2015) adalah suatu kebijakan dan keputusan yang menyangkut bentuk dan komposisi pendanaan yang akan digunakan oleh perusahaan. Keputusan ini merupakan keputusan manajemen yang akan menimbang dan menganalisis perpaduan sumber-sumber dana yang paling ekonomis bagi perusahaan untuk mendanai kebutuhan-kebutuhan operasional dan investasi perusahaan. Keputusan pendanaan oleh manajemen ini akan berpengaruh pada penilaian perusahaan yang terefleksi di harga saham. Menurut model trade -off penggunaan utang akan meningkatkan nilai perusahaan tapi hanya sampai titik tertentu (titik balik/struktur modal yang optimal). Setelah melewati titik balik, penggunaan hutang akan menurunkan nilai perusahaan karena keuntungan dari penggunaan utang tidak sebanding kenaikan biaya financial distress dan agency problem (Atmaja, 2008). Menurut Arieska dan Gunawan (2011) peningkatan pendanaan melalui utang merupakan salah satu alternatif untuk mengurangi biaya keagenan. Hutang dapat mengendalikan manajer untuk mengurangi tindakan perquisites dan kinerja perusahaan menjadi lebih efisien.

\section{Pengembangan Hipotesis}

\section{Pengaruh Likuiditas terhadap Nilai Perusahaan}

Likuiditas yang dimaksud dalam penelitian ini adalah manajemen modal kerja, menurut Sartono (2010) manajemen modal kerja berelasi terhadap keputusan investasi pada aktiva lancar dan utang lancar terutama mengenai bagaimana menggunakan dan komposisi keduanya akan mempengaruhi resiko likuiditas. Kebijakan modal kerja merupakan trade off antara risiko dan return, modal kerja yang tinggi akan menurunkan risiko perusahaan, namun profitabilitas akan menurun (hanafi, 2016). Beberapa hasil studi empiris terdahulu menunjukkan bahwa likuiditas berpengaruh signifikan positif terhadap nilai perusahaan (Mehta, 2012; Pasarib, 2008). Hasil ini diperkuat oleh Ristanti et al, (2015) yang meneliti pada perusahaan Food and Baverage di BEI tahun 2011-2103 menemukan bahwa likuiditas yang diproksikan Current Ratio berpengaruh 
positif dan signifikan terhadap profitabilitas (ROI) perusahaan. Berdasarkan hasil penjelasan telaah pustaka dan uraian beberapa penelitian diatas, maka dapat diajukan hipotesis pada penelitian ini adalah :

H1 : Likuiditas berpengaruh signifikan terhadap nilai perusahaan

\section{Pengaruh Keputusan Pendanaan terhadap Nilai Perusahaan}

Pendanaan perusahaan melalui utang dapat meningkat nilai perusahaan dan sebaliknya, penelitian tentang penggunaan utang ini sangat beragam, menurut Trade-off theory atau balancing theory yang didasarkan pada pelonggaran asumsi Modigliani dan Miller (1963) penggunaan utang akan meningkatkan nilai perusahaan sampai pada batas tertentu. Teori tersebut menyatakan bahwa bila pajak perseroan dan biaya kebangkrutan dipertimbangkan, maka hubungan leverage utang dengan nilai perusahaan adalah non-linier. Jadi pada batas tertentu penggunaan utang akan meningkatkan nilai perusahaan, yaitu penggunaan hutang yang memberi manfaat berupa penghematan pajak. Namun jika pada titik dimana biaya kebangkrutan melebihi manfaat penghematan pajak, maka penggunaan utang akan menurunkan nilai perusahaan (Hanafi, 2016). Konsisten dengan teori trade-off, Arieska dan Gunawan (2011); Abidin, et al (2014); Laksitaputri (2012); Hamidy (2015) menguji pengaruh keputusan pendanaan dan nilai perusahaan, hasilnya menunjukkan bahwa keputusan pendanaan berpengaruh signifikan dan positif terhadap nilai perusahaan. Berdasarkan pada telaah pustaka dan uraian beberapa penelitian diatas, pendanaan melalui utang akan menigkatkan nilai perusahaan. Dengan demikian hipotesis yang diajukan adalah sebagai berikut :

\section{H2 : keputusan pendanaan berpengaruh siginifikan terhadap nilai perusahaan}

\section{Pengaruh Kinerja Perusahaan dan Nilai Perusahaan}

Kinerja perusahaan bagi investor adalah gambaran atau signal untuk memutuskan apakah investasi akan dilakukan. Menurut teori signaling, perusahaan yang profitabilitasnya tinggi akan membayar dividen yang tinggi pula (Wiyono dan Kusuma, 2017). Kinerja perusahaan yang tinggi merupakan sebagai signal positif sebagai informasi bahwa perusahaan memiliki prospek yang baik dan akan membayar dividen. Kinerja perusahaan yang baik akan menarik minat investor untuk berinvestasi pada perusahaan tersebut, sehingga nilai perusahaan akan naik. Berbagai studi telah dilakukan untuk membuktikan bahwa kinerja perusahaan berhubungan positif dan signifikan dengan nilai perusahaan (diantaranya hasil studi Mai, 2012; Sudiyatno, 2010; Irmawati, 2012; Sukoco, 2013; Putri,et al, 2016; Safitri,et al, 2014; Hidayati, 2008; Hamidy, 2015 ). Sudiyatno (2010) meneliti pada 116 perusahaan manufaktur di Bursa Efek Indonesia, menganalisis pengaruh kinerja perusahaan dengan proksi return on asset terhadap nilai perusahaan dengan proksi Tobins q ratio. Hasil studi ini menunujukkan bahwa ROA berpengaruh positif dan signifikan terhadap nilai Tobins $Q$. Bedasarkan teori dan penelitianpenelitian terdahulu dapat maka ditarik hipotesis berikut :

\section{H3 : Kinerja perusahaan berpengaruh positif dan signifikan terhadap nilai perusahaan}

GCG memoderasi hubungan Likuiditas dan Nilai Perusahaan, Kinerja perusahan dan Nilai Perusahaan, serta Keputusan Pendanaan dan Nilai perusahaan.

Berdasarkan teori keagenan, masalah keagenan muncul karena adanya konflik kepentingan antara dua pihak, misal antara prinsipal dan manajer atau antara pemegang saham mayoritas dan minoritas (Jensen dan Meckling, 1976). Mekanisme tata kelola merupakan media untuk mengurangi konflik kepentingan antar para pemangku kepentingan (Shleifer dan Vishny, 1997). Berikut ini beberapa penelitian terdahulu mengenai tata kelola perusahaan terhadap nilai 
perusahaan, Siagian et al (2013) menemukan Corporate Governance Index (CGI) secara positif berpengaruh terhadap price to book value (PBV). Konsisten dengan penelitian diatas, Aren et al (2014), Sulistiyono (2010), Putri (2014) menemukan bahwa tata kelola perusahaan yang baik akan berpengaruh signifikan pada nilai perusahaan.

Berdasarkan penelitian Bai et al dan Hanifah (dalam Almaarneh'a, 2014) menyatakan kepemilikan asing memiliki pengaruh yang positif terhadap peningkatan nilai perusahaan. kepemilikan saham asing akan meningkatkan pengungkapan informasi yang lebih pada laporan tahunan perusahaan tersebut. Pengungkapan informasi yang lebih akan menarik investor lokal dan asing lain untuk menanamkan modalnya pada perusahaan tersebut.

Fama dan Jensen (1983) berpendapat bahwa komisaris independen dapat bertindak sebagai penengah dalam masalah agensi yang terjadi antara para manajer internal dan mengawasi kebijakan manajemen serta dapat memberikan masukan kepada pihak internal perusahaan. Semakin tinggi dewan komisaris independen maka akan semakin ketat pengawasan terhadap manajemen, sehingga penyalahgunaan aset dan manipulasi transaksi asset perusahaan dapat diawasi secara efektif. Dengan demikian, biaya keagenan akan semakin kecil, efisien, dan nilai perusahaan akan meningkat pula. Berdasarkan penelitian-penelitian diatas maka ditarik hipotesis penelitian sebagai berikut :

H4 : GCG berpengaruh langsug terhadap nilai perusahaan

H5 : GCG memperkuat hubungan antara Likuiditas perusahaan dan nilai perusahaan

H6 : GCG memperkuat hubungan antara Kinerja perusahaan dan nilai perusahaan

H7 : GCG memperkuat hubungan antara keputusan pendanaan perusahaan dan nilai perusahaan

Kinerja Perusahaan Memediasi Pengaruh Likuiditas terhadap Nilai Perusahaan

Dalam penentuan kebijakan modal kerja yang efisien, perusahaan dihadapkan pada masalah adanya pertukaran (trade off) antara faktor likuiditas dan profitabilitas (Hanafi, 2016; Van Horne, 1998). Jika perusahaan memutuskan menetapkan modal kerja dalam jumlah yang besar, kemungkinan tingkat likuiditas akan terjaga namun kesempatan untuk memperoleh laba yang besar akan menurun yang pada akhirnya berdampak pada menurunnya profitabilitas. Berbagai studi telah dilakukan untuk menjelaskan hubungan antara likuiditas terhadap kinerja perusahaan / profitabilitas (dapat dilihat dalam: Ristanti, et al, 2015; Mehta, 2012). Mereka menjelaskan bahwa likuiditas perusahaan berpengaruh signifikan terhadap profitabilitas perusahaan. Berdasarkan uraian penelitian-penelitian sebelumnya dan kerangka berpikir, maka diajukan hipotesis sebagai berikut :

H8: Kinerja perusahaan memediasi hubungan antara likuiditas terhadap nilai perusahaan

\section{Kinerja Perusahaan Memediasi Pengaruh Keputusan Pendanaan terhadap Nilai Perusahaan}

Kinerja Perusahaan/Profitabilitas yang diproksi dengan Net Profit Margin (NPM), Return on Asset (ROA), dan Return on Equity (ROE) digunakan sebagai variabel intervening dalam hubungan kausalitas antara keputusan pendanaan dan nilai perusahaan. Digunakannya profitabilitas sebagai variabel intervening dalam model penelitian empiris ini berdasarkan beberapa penelitian yang menguji pengaruh profitabilitas terhadap nilai perusahaan menunjukkan hasil yang positif dan signifikan (dapat dilihat dalam: Sukoco, 2013; Irmawati, 2012; Safitri, et al, 2014; Hidayati, 2008; Laksitaputri, 2012; Hamidy, 2015; Putri, et al, 2016; Sudiyatno, et al, 2012; Mai, 2012). Sedangkan penelitian yang menguji pengaruh keputusan pendanaan terhadap nilai 
perusahaan, menunjukkan hasil masih simpangsiur, seperti penelitian yang dilakukan oleh Efni, et al 2012 pada sektor yang sama menemukan bahwa keputusan pendanaan tidak berpengaruh signifikan terhadap nilai perusahaan, hasil ini bertentangan dengan teori MM dengan pajak yang mengemukakan pendanaan menggunakan utang akan meningkatkan nilai perusahaan akibat adanya penghematan pajak.

\section{H9 : Kinerja Perusahaan Memediasi Hubungan antara Keputusan Pendanaan terhadap Nilai Perusahaan}

\section{METODOLOGI PENELITIAN}

\section{Jenis dan Sumber Data Penelitian}

Jenis data yang digunakan merupakan data sekunder. Data yang diperoleh bersumber dari laporan keuangan, dan laporan tahunan perusahaan yang telah diaudit dan dipublikasikan di Bursa Efek Indonesia, dari tahun 2015 hingga 2017. Populasi dalam penelitian ini adalah perusahaan property, real estate, dan building construction yang terdaftar di Bursa Efek Indonesia. Pengambilan sampel dilakukan dengan metode purposive sampling. Jumlah populasi 57 perusahaan yang memenuhi kriteria sebanyak 44 perusahaan, maka data penelitian $44 \times 3$ tahun yaitu 132 data.

\section{Metode Analisis dan Hipotesis Penelitian}

Pengujian dilakukan dengan uji statistik deskriptif, kemudian dilakukan pengolahan data dengan alat analisis Partial Least Square (PLS) yang meliputi uji outer model, uji inner model, uji hipotesis secara langsung, uji hipotesis moderasi, dan uji mediasi dengan metode pemeriksaan.

\section{Operasional Variabel Penelitian}

Berikut ini beberapa variabel dan defenisi operasional variabel yang digunakan dalam penelitian ini :

1. Nilai Perusahaan, variabel dependen dalam penelitian ini adalah nilai perusahaan dan diproksikan dalam indikator Tobins Q, PER, dan PBV.

a. Price Earning Ratio (PER) merupakan rasio fundamental, yang membandingkan antara harga pasar saham perusahaan dengan earning per share perusahaan (Hanafi, 2016).

b. Price to Book Value, merupakan salah satu rasio pasar, membandingan antara harga saham perlembar dengan nilai buku ekuitas per lembar saham (Husnan dan Pudjiastuti, 2015)

c. Tobins $Q$ adalah rasio yang membandingkan nilai kapitalisasi pasar perusahaan dan utang perusahaan dengan total aset perusahaan (Sudiyatno, 2010; Putri, et al, 2016)

2. Likuiditas merupakan variabel independen yang diukur dengan current ratio, quick ratio, dan cash ratio

a. Current ratio adalah Perbandingan antara aset lancar dengan utang lancar (Fahmi, 2015).

b. Quick ratio adalah perbandingan aset lancar yang dikurang persediaan dibagi dengan utang lancar (Hanafi, 2016).

c. Cash Ratio adalah perbandingan antara kas dengan utang lancar (Rodoni dan Ali, 2014)

3. Keputusan pendanaan merupakan variabel independen yang diukur dengan debt to equity ratio, debt to asset ratio, dan long term debt to equity ratio.

a. DER adalah rasio yang membandingkan total utang dengan total modal (Kasmir, 2014)

b. DAR adalah perbandingan antara total utang dengan total aset (Kasmir, 2014) 
c. LDER adalah perbandingan antara total utang jangka panjang dengan total modal (Kasmir, 2014)

4. Kinerja Perusahaan

a. NPM adalah rasio pembanding antara laba bersih dengan total penjualan/pendapatan perusahaan (Rodoni dan Ali, 2014)

b. ROA adalah rasio pembanding antara laba bersih dengan total aset perusahaan (Hanafi dan Halim, 2012).

c. ROE adalah rasio antara laba bersih dengan total modal perusahaan (Hanafi,2016).

5. Good corporate governance

a. Kepemilikan asing adalah perbandinngan jumlah saham yang dimiliki asing dibagi dengan total saham perusahaan (Andreas, 2009)

b. Board size atau ukuran dewan komisaris merupakan jumlah seluruh dewan komisaris (Mai,2012 dan Tang, 2007).

c. Komisaris independen adalah perbandingan jumlah komisaris independen dengan seluruh komisaris perusahaan (Mai, 2012).

d. Komite audit adalah perbandingan anggota komite audit terhadap seluruh anggota komisaris (Sixpria dan Suhartati, 2013).

\section{HASIL DAN PEMBAHASAN}

\section{Uji Inner Model (Model Struktural)}

Tahap selanjutnya adalah melakukan evaluasi struktural (inner model) yang meliputi uji kecocokan model (model fit), Menilai predictive relevance (Q2), dan Koefisien Determinasi (R2).

\section{Uji Kecocokan (Model Fit Indices)}

Pada uji kecocokan model terdapat 3 indeks pengujian, yaitu average path coefficient (APC), average R-squared (ARS) dan average varians factor (AVIF) dengan kriteria APC dan ARS diterima dengan syarat $p$-value $<0,05$ dan AVIF $<5$ (Sholihin dan Ratmono, 2013).

Tabel 5. General SEM Analysis Result

\begin{tabular}{ccc}
\hline & Indeks & $\boldsymbol{P}$-Value \\
\hline APC & 0.134 & $\mathrm{P}<0.012$ \\
ARS & 0.106 & $\mathrm{P}=1.529$ \\
AVIF & 1.342 & Good if $<5$ \\
\hline \multicolumn{2}{l}{ Sumber: Hasil olah data program WarpPLS 3.0 }
\end{tabular}

Dari tabel diatas menunjukkan bahwa nilai APC sebesar 0.134 dan nilai $p$-value sebesar 0.012 , nilai ARS sebesar 0.106 dan nilai $p$-value sebesar 1.529 , nilai AVIF sebesar 1,342 . Berdasarkan kriteria, APC telah memenuhi kriteria karena memiliki nilai $p$-value sebesar 0,012 karena syaratnya adalah nilai $p$-value $<0,05$. Sedangkan nilai ARS tidak memenuhi kriteria karena memiliki nilai $p$-value sebesar 1,348 karena syaratnya adalah nilai $p$-value $<0,05$. Selanjutnya, berdasarkan data tersebut nilai AVIF sebesar 1.342, AVIF sudah memenuhi kriteria karena nilai AVIF dibawah 5 yang menjadi syarat terpenuhinya kriteria. Dari data tersebut dapat disimpulkan bahwa inner model dapat diterima, namun tidak signifikan. 


\section{Menilai R-Squares (R2)}

Dari tabel 4 diatas, diperoleh nilai $\mathrm{R}$ Square variabel Nilai Perusahaan sebesar 0.137 , Artinya adalah sebesar $13.7 \%$ variabel Nilai Perusahaan dipengaruhi oleh Keputusan Pendanaan, Kinerja Perusahaan. Kemudian nilai R Square variabel Kinerja Perusahaan sebesar 0.075 , Artinya adalah sebesar $7.5 \%$ variabel kinerja perusahaan dipengaruhi oleh Likuiditas dan Keputusan Pendanaan.

\section{Menilai Predictive Relevance (Q2)}

Selanjutnya dari hasil diatas dapat diperoleh nilai predictive-relevance $\left(Q^{2}\right)$ dengan persamaan sebagai berikut:

$\mathrm{Q}^{2}=1-\left(1-\mathrm{R} 1^{2}\right)\left(1-\mathrm{R} 2^{2}\right)$

$Q^{2}=0,2017$

Hasil diatas dapat diartikan bahwa sebesar 20,17\% nilai perusahaan dipengaruhi oleh variabel Likuiditas, Keputusan Pendanaan, Kinerja Perusahaan, dan Tata Kelola Perusahaan, sisanya sebesar $79,73 \%$ dijelaskan oleh faktor lainnya di luar model.

\section{Pengujian Pengaruh Langsung}

Tabel 6. Hasil Pengujian Hipotesis

\begin{tabular}{|c|c|c|c|c|c|}
\hline NO & Hubungan antar Variabel & & Koef.Jalur & $p$-value & Keterangan \\
\hline 1 & Likuiditas & Nilai Perusahaan & -0.165 & 0.141 & Tidak Siqnifikan \\
\hline 2 & Keputusan Pendanaan & Nilai Perusahaan & 0.136 & 0.089 & Signifikan \\
\hline 3 & Kinerja Perusahaan & Nilai Perusahaan & 0.181 & 0.054 & Signifikan \\
\hline 4 & GCG & Nilai Perusahaan & -0.024 & 0.393 & Tidak Signifikan \\
\hline
\end{tabular}

Hasil pengujian pada tabel 6 menunjukkan bahwa : likuiditas tidak berpengaruh signifikan terhadap nilai perusahaan, $p$-value 0.141 lebih besar dari 0.10 , artinya hipotesis 1 ditolak. Keputusan pendanaan berpengaruh signifikan terhadap nilai perusahaan, $p$-value 0.089 kurang 0.10 , artinya hipotesis 2 diterima. Kinerja perusahaan berpengaruh signifikan terhadap nilai perusahaan, p-value 0.054 kurang dari 0.10 , artinya hipotesis 3 diterima. Good corporate governance tidak berpengaruh signifikan terhadap nilai perusahaan, $p$-value 0.393 lebih besar dari 0.10 , artinya hipotesis 4 ditolak.

\section{Pengujian Pengaruh Variabel Moderasi}

Tabel. 7 Hasil Pengujian Hipotesis dengan Variabel Moderasi

\begin{tabular}{ccccccc}
\hline No & \multicolumn{1}{c}{ Var. Penjelas } & $\begin{array}{c}\text { Var.Mod } \\
\text { erasi }\end{array}$ & Var. Respon & $\begin{array}{c}\text { Koef. Jalur } \\
\text { Moderasi }\end{array}$ & P-value & Keterangan \\
\hline 1 & Likuiditas & GCG & Nilai Perusahaan & 0.036 & 0.361 & Tidak Memoderasi \\
2 & Kinerja Perusahaan & GCG & Nilai Perusahaan & -0.168 & 0.245 & Tidak Memoderasi \\
3 & Keputusan Pendanaan & GCG & Nilai Perusahaan & 0.108 & 0.232 & Tidak Memoderasi \\
\hline
\end{tabular}

Sumber : Hasil Olah Data Program WarpPLS 3.0

Berdasarkan hasil pengujian pada tabel 7 diatas, GCG tidak memoderasi hubungan likuiditas terhadap nilai perusahaan, p-value 0.361 lebih besar dari 0.10 , artinya hipotesis 5 ditolak. GCG tidak memoderasi hubungan kinerja perusahaan terhadap nilai perusahaan, $p$-value 0.245 lebih 
besar dari 0.10 , artinya hipotesis 6 ditolak. GCG tidak memoderasi hubungan keputusan pendanaan terhadap nilai perusahaan, $p$-value 0.232 lebih besar dari 0.10 , artinya hipotesis 7 ditolak.

\section{Pengujian Variabel Mediasi}

\section{Kinerja Perusahaan Memediasi pengaruh Likuiditas terhadap Nilai Perusahaan}

Tabel 8 Hasil Pengujian Hipotesis Secara Langsung Tanpa Variabel Mediasi

\begin{tabular}{|c|c|c|c|c|c|}
\hline $\mathrm{NO}$ & \multicolumn{2}{|c|}{ Hubungan antar Variabel } & Koef.Jalur & \multirow{2}{*}{$\begin{array}{l}p \text {-value } \\
0.025\end{array}$} & \multirow{2}{*}{$\begin{array}{l}\text { Keterangan } \\
\text { Signifikan }(p c)\end{array}$} \\
\hline 1 & Likuiditas $\quad \mathrm{Ni}$ & ai Perusahaan & 198 & & \\
\hline \multicolumn{6}{|c|}{ Sumber : Hasil Olah Data Program WarpPLS 3.0} \\
\hline \multicolumn{6}{|c|}{ Tabel 9 Hasil Pengujian Hipotesis dengan Variabel Mediasi } \\
\hline NO & Hubungan antar Var & abel & Koef.Jalur & p-value & Keterangan \\
\hline 1 & Likuiditas & Nilai Perus & -0.165 & 0.141 & Tidak Signifikan ( $\mathrm{P}$ \\
\hline 2 & Likuiditas & Kinerja Perusahaan & -0.204 & 0.004 & Signifikan $(\mathrm{Pa})$ \\
\hline 3 & Kinerja Perusahaan & Nilai Perusahaan & 0.181 & 0.054 & Signifikan $(\mathrm{Pb})$ \\
\hline
\end{tabular}

Sumber : Hasil Olah Data Program WarpPLS 3.0

Hasil analisis tanpa variabel mediasi diperoleh hubungan antara likuiditas terhadap nilai perusahaan signifikan $(\mathrm{Pc})$. Hasil pengujian dengan variabel mediasi diperoleh hubungan antara likuiditas dan nilaiperusahaan tidak signifikan ( $\left(\mathrm{C}^{\prime}\right)$. Hubungan antara likuiditas terhadap kinerja perusahaan signifikan $(\mathrm{Pa})$. Hubungan antara kinerja perusahaan dan nilaiperusahaan signifikan $(\mathrm{Pb})$. Berdasarkan metode pemeriksaan maka kinerja perusahaan merupaka variabel mediasi, karena Pc signifikan, Pc' tidak signifikan, $\mathrm{Pa}$ dan $\mathrm{Pb}$ signifikan. Hipotesis 8 diterima.

Kinerja Perusahaan Memediasi pengaruh keputusan Pendanaan terhadap Nilai Perusahaan

Tabel 10. Hasil Pengujian Hipotesis Secara Langsung Tanpa Variabel Mediasi

\begin{tabular}{clllll}
\hline NO & Hubungan antar Variabel & Koef.Jalur & $p$-value & Keterangan \\
\hline 1 & Keputusan Pendanaan & Nilai Perusahaan & 0.149 & 0.078 & Signifikan (Pc) \\
\hline Sumber : Hasil Olah Data Program WarpPLS 3.0 & & &
\end{tabular}

Sumber : Hasil Olah Data Program WarpPLS 3.0

Tabel 11. Hasil Pengujian Hipotesis dengan Variabel Mediasi pada Hubungan Keputusan terhadap Nilai Perusahaan

\begin{tabular}{clllll}
\hline NO & Hubungan antar Variabel & & Koef.Jalur & p-value & Keterangan \\
\hline 1 & Keputusan Pendanaan & Nilai Perusahaan & 0.136 & 0.089 & Signifikan (Pc') \\
2 & Keputusan Pendanaan & Kinerja Perusahaan & -0.185 & 0.056 & Signifikan (Pa) \\
3 & Kinerja Perusahaan & Nilai Perusahaan & 0.181 & 0.054 & Signifikan (Pb) \\
\hline
\end{tabular}

Sumber : Hasil Olah Data dengan Program WarpPLS 3.0

Analisis tanpa variabel mediasi menunjukkan koefisien jalur c pada tabel $10=0.149$ dan $P_{c}$-value 0.078 , artinya signifikan pada level kurang dari $10 \%$. Selanjutnya analisis dengan variabel mediasi menunjukkan nilai koefisien jalur $c^{\prime}=0.136$ dan $P_{C^{\prime}}=0.089$ (lihat tabel 11), artinya signifikan pada level signifikansi kurang $10 \%$. Koefisien jalur $a=-0.185$ dan $\mathrm{P}_{\mathrm{a}}$ value 0.056 , artinya signifikan kurang dari 0.10 (lihat tabel 11), Kemudian nilai koefisien jalur antara kinerja perusahaan dan nilai perusahaan $b=0.181$ dan $P_{b}=0.054$ (lihat tabel 11), artinya 
signifikan pada level kurang dari 0.10 . Berdasarkan metode pemeriksaan kinerja perusahaan merupakan variabel mediasi antara keputusan pendanaan terhadap nilai perusahaan, karena memenuhi persyaratan metode pemeriksaan yaitu, $\mathrm{Pc}, \mathrm{Pc}, \mathrm{Pa}, \mathrm{Pb}$ signifikan dan koefisien jalur Pc' lebih kecil dari Pc. Hipotesis 9 diterima.

\section{Pembahasan}

Berdasarkan hasil penelitian ini diperoleh likuiditas berpengaruh negatif tetapi tidak signifikan terhadap nilai perusahaan, pengaruhnya sangat sedikit atau bisa dikatakan bahwa likuiditas tidak berpengaruh terhadap nilai perusahaan. Hal ini dikarenakan likuiditas merupakan kemampuan perusahaan dalam mengurangi utang jangka pendek, hal ini menunjukkan bahwa likuiditas berorientasi pada jangka pendek, sedangkan nilai perusahaan berorientasi pada jangka panjang, sehingga kebijakan modal kerja atau likuiditas ini tidak menunjukkan adanya pengaruh yang signifikan terhadap nilai perusahaan. Hasil ini konsisten dengan penelitian Irmawati (2012); Sukoco (2013); Putri, et al (2016).

Berdasarkan hasil penelitian ini diperoleh keputusan pendanaan berpengaruh positif dan signifikan terhadap nilai perusahaan, artinya peningkatan pendanaan perususahaan melalui utang akan diikuti peningkatan nilai perusahaan. karena Peningkatan pendanaan melalui utang ini akan memberikan manfaat penghematan pajak dan nilai perusahaan akan meningkat sampai pada batas tertentu, dimana biaya kebangkrutan (financial distress) dan biaya keagenan (agency cost) tidak melebihi biaya penghematan pajak (tax shield), namun jika melebihi biaya tersebut maka penggunaan utang akan menurunkan nilai perusahaan. Hasil ini mendukung teori trade off dan beberapa penelitian terdahulu seperti Laksitaputri (2012); Abidin, et al (2014); Hamidy, 2015; Sudiyatno (2010).

Bedasarkan hasil penelitian ini diperoleh kinerja perusahaan berpengaruh signifikan positif terhadap nilai perusahaan, artinya peningkatan kinerja perusahaan akan meningkatkan nilai perusahaan. Hasil ini sesuai dengan perkiraan sebelumnya dan mendukung argumentasi teori signaling, kinerja yang baik menunjukkan perusahaan memiliki prospek yang baik dan akan mampu membayar dividen yang tinggi pula (Wiyono dan Kusuma, 2017). Hasil ini konsisten dengan beberapa penelitian terdahulu Irmawati (2012); Sukoco(2013); Safitri, et al (2014); Hidayati (2008); Putri, et al (2016).

Berdasarkan hasil penelitian ini diperoleh Good Corporate Governace (GCG) berpengaruh negatif dan tidak signifikan terhadap nilai perusahaan. Peningkatan boardsize pada perusahaan akan menurunkan nilai perusahaan, karena perusahaan yang memiliki ukuran dewan yang besar tidak bisa melakukan pengambilan keputusan yang lebih baik dibandingkan dengan perusahaan yang memiliki ukuran dewan yang kecil, sehingga nilai perusahaan turun. Selain itu, perusahaan dengan ukuran dewan komisaris kecil, lebih efektif dalam mewakili kepentingan para pemegang saham.

Good Corporate Governance (GCG) tidak berpengaruh dalam memperkuat hubungan antara likuiditas terhadap nilai perusahaan. Penerapan good corporate governance khususnya boardsize pada perusahaan belum dapat meningkatkan efektifitas dan efisiensi dalam pengelolaan perusahaan. Dari sisi eksternal penerapan GCG belum mendapatkan respon yang positif, karena investor melihat profitabilitas yang masih turun, adanya fungsi GCG yang belum mampu mengontrol manajemen dalam mengelola modal kerja. 
Berdasarkan hasil penelitian ini diperoleh GCG berpengaruh negatif tetapi tidak signifikan dalam memoderasi hubungan antara kinerja perusahaan dan nilai perusahaan. Artinya adanya mekanisme GCG, seperti penambahan ukuran dewan komisaris belum mampu meningkatkan kinerja perusahaan dan nilai perusahaan. karena manajemen merasa terlalu diawasi sehingga timbul konflik keagenan, biaya keagenan meningkat seiring bertambahnya biaya pengawasan. Penurunan kinerja memberikan signal negatif bagi para pelaku pasar modal, mengakibatkan nilai perusahaan turun. Hal ini tidak sesuai dengan argumentasi teori signaling (Ross, 1977 dalam Hanafi, 2016). Selain itu, ukuran dewan yang besar tidak efektif dibandingkan dewan yang kecil, ukuran dewan yang besar mengakibatkan lebih sukar untuk mengadakan pertemuan-pertemuan, mencapai kesepakatan / konsensus, hal ini disebabkan oleh komunikasi dan biaya koordinasi yang meningkat. (jensen, 1993 dalam Mai, 2012).

Berdasarkan hasil penelitian ini diperoleh GCG berpengaruh positif, tetapi tidak signifikan dalam memoderasi hubungan antara keputusan pendanaan dan nilai perusahaan. Adanya penerapan Good Corporate Governance (GCG) yaitu ukuran dewan komisaris (board size) pada perusahan-perusahaan disektor ini belum memberikan pengaruh yang signifikan terhadap nilai perusahaan. Penambahan dewan komisaris tidak berpengaruh signifikan terhadap manajemen dalam melakukan kebijakan pendanaan, pendanaan dalam bentuk utang. Sehingga kinerja perusahaan masih menurun. Karena penambahan dewan komisaris belum dapat meningkatkan efektivitas pengambilan keputusan, waktu yang digunakan dalam pengambilan keputusan tidak efisien dan keputusan yang diambil memiliki kualitas yang buruk sehingga tidak dapat menarik investor dan menyebabkan harga saham/nilai perusahaan masih rendah.

Berdasarkan hasil penelitian ini diperoleh kinerja perusahaan memediasi pengaruh likuiditas terhadap nilai perusahaan. Secara empiris hubungan antara likuiditas dan kinerja perusahaan adalah berpengaruh negatif dan signifikan terhadap kinerja perusahaan. Likuiditas yang tinggi akan berpengaruh terhadap penurunan profitabilitas perusahaan. Karena modal kerja yang tinggi akan menurunkan resiko likuiditas, tetapi profitabilitas akan menurun (Hanafi, 2016). Akibat adanya penggunaan aktiva lancar yang tidak efisien, sehingga menurunkan kinerja perusahaan. Penurunan kinerja perusahaan bagi para pelaku pasar modal merupakan signal negatif, sehingga nilai perusahaan turun. Secara empiris hasil penelitian ini sesuai dengan teori signaling. Ketika kinerja perusahaan meningkat akan ditangkap pasar sebagai signal informasi positif tentang adanya dividend yield dimasa yang akan datang atau sebaliknya juga (Hanafi, 2016; Sudiyatno, 2010; Mai, 2012).

Berdasarkan hasil penelitian ini diperoleh kinerja perusahaan memediasi hubungan antara keputusan pendanaan terhadap nilai perusahaan. Berdasar hasil pengujian statistik menunjukkan keputusan pendanaan berpengaruh negatif dan signifikan terhadap kinerja perusahaan, peningkatan utang akan berpengaruh terhadap penurunan profit perusahaan. karena penggunaan utang pada sebagian besar perusahaan property di BEI belum menghasilkan laba yang maksimal, sehingga rate of return dari penggunaan utang lebih kecil dari biaya modalnya atau biaya bunga dari penggunaan utang lebih besar dari pada keuntungan dari penghematan pajak, sehingga kinerja perusahaan turun. Hal ini sesuai dengan teori trade off. Sedangkan kinerja perusahaan berpengaruh positif dan signifikan terhadap nilai perusahaan, sesuai dengan konsep teori signaling. Kinerja perusahaan yang turun akan berpengaruh terhadap penurunan nilai perusahaan. 


\section{KESIMPULAN DAN REKOMENDASI KEBIJAKAN}

\section{Kesimpulan}

Hasil penelitian menemukan bahwa sebesar $20,17 \%$ nilai perusahaan dipengaruhi oleh variabel likuiditas, keputusan pendanaan, kinerja perusahaan, dan tata kelola perusahaan, sisanya sebesar $79,73 \%$ dijelaskan oleh faktor lainnya di luar model. Likuiditas dan good corporate governance tidak berpengaruh terhadap nilai perusahaan. Namun, Keputusan pendanaan dan kinerja perusahaan berpengaruh terhadap nilai perusahaan. Good corporate governance tidak memoderasi hubungan likuiditas terhadap nilai perusahaan, kinerja perusahaan terhadap nilai perusahaan, dan keputusan pendanaan terhadap nilai perusahaan. Likuiditas berpengaruh signifikan terhadap nilai perusahaan melalui kinerja perusahaan. Keputusan pendanaan berpengaruh signifikan terhadap nilai perusahaan melalui kinerja perusahaan.

\section{Rekomendasi Kebijakan}

Berdasarkan hasil penelitian dan pembahasan sebelumnya dapat ditarik beberapa rekomendasi dan kebijkan, antra lain : Manajemen perusahaan diharapkan dapat memanfaatkan penggunaan aktiva lancar secara efisien, sehingga profitabilitas perusahaan dapat meningkat, Penelitian selanjutnya perlu mempertimbangkan sampel yang lebih luas, tidak hanya pada perusahaan Property, Real Estate, Building Construction saja, tetapi juga pada perusahaan lain yang terdapat di Bursa Efek Indonesia agar kesimpulan yang dihasilkan memiliki cakupan yang lebih luas.

\section{DAFTAR PUSTAKA}

Abidin, Zainal., Meina, W.Y., dan Muhamad, Z. 2014. Pengaruh Struktur Modal, Kebijakan Dividen, dan Size, Terhadap Nilai Perusahaan: Studi Pada Perusahaan Peroperti di BEI. Jurnal Wawasan Manajemen. Vol 2. No 3. Oktober.

Arieska, Metha,. dan Barbara Gunawan. 2011. Pengaruh Aliran Kas Bebas dan Keputusan Pendanaan Terhadap Nilai Pemegang Saham dengan Set Kesempatan Investasi dan Dividen Sebagai Variabel Moderasi, Jurnal Akuntansi Dan Keuangan, Vol. 13, No. 1, Mei : 13-23.

Atmaja, Lukas Setia. 2008. Teori dan Praktik Manajmen Keuangan. Edisi I. Andi Yogyakarta. Yogyakarta.

Chowdhury, Anup dan Suman Paul Chowdhury. 2010. Impact of capital structure on firms value: evidence from Bangladesh. Bussiness and Economic Horizons.

Efni, Yulia., Djumilah Hadiwidjoyo., Salim Ubud., Rahayu Minarti. 2012. Keputusan Investasi, Keputusan Pendanaan, Kebijakan Deviden :Pengaruhnya Terhadap Nilai Perusahaan. Jurnal Aplikasi Manajemen. Vol.10. No.1. hal 128-141.

Fahmi, Irham. 2015. Etika Bisnis: Teori, Kasus, dan Solusi. Cetakan Ketiga. Alfabeta. Bandung.

Fama, E. F, 1978. The Effect of a Firmm's Investment and Financing Decision on the Welfareof its Security Holders. American Economic Review. 68 : 272-288.

Ghozali, I., dan H. Latan. 2014. Partial Least Squares; Konsep, Metode, dan Aplikasi Menggunakan Program WarpPLS 4.0. Badan Penerbit Universitas Diponegoro. Semarang.

Hamidy, Rahman Rusdi., I Gusti Bagus Wiksuana., Luh Gede Sri Artini. 2015. Pengaruh Struktur Modal Terhadap Nilai Perusahaan Dengan Profitabilitas Sebagai Variabel Intervening Pada Perusahaan Properti Dan Real Estate Di Bursa Efek Indonesia. Jurnal Ekonomi dan Bisnis Universitas Udayana 
Hanafi, M, Mamduh. 2016. Manajemen Keuangan. Edisi Kedua. BPFE-Yogyakarta. Yogyakarta.

Hanafi, M, Mamduh dan A. Halim. 2012. Analisis Laporan Keuangan. Edisi Keempat. Cetakan Kedua. Sekolah Tinggi IImu Manajemen YKPN. Yogyakarta.

Hidayati, Eva Eko. 2008. Analisis Pengaruh DER, DPR, ROE, dan SIZE Terhadap PBV Perusahaan Manufaktur yang Listing Di BEI Periode 2005-2007. Jurnal. Magister Manajemen Universitas Diponegoro.

Horne, James C. Van dan John M. Machowicz. JR. 2009. Financial Manajemen: Prinsip-prinsip Manajemen Keuangan Buku 1. Edisi 12. Salemba Empat. Jakarta

Husnan, S., dan Pudjiastuti, E. 2015. Dasar-Dasar Manajemen Keuangan. Edisi Ketujuh. UPP STIM YKPN. Yogyakarta.

Jensen, M. C., and Meckling, W.H. 1976. Theory of the Firm : Managerial Behavior,Agency Costs and Ownership Structure. Journal of Financial Economics.Vol. 3. No. 4. Oktober. pp. 305-360.

Kasmir. 2014. Analisis Laporan Keuangan. Edisi Satu. Cetakan Ketujuh. PT Raja Grafindo Persada. Jakarta

Mai, M, U. 2010. Dampak Kebijakan Dividen Terhadap Nilai Perusahaan Dalam Kajian Oportunistik Manajerial Dan Struktur Corporate Governance. Disertasi. Universitas Diponegoro. Semarang.

Mardiyati, Umi., Gatot Nazir Ahmad dan Ria Putri. 2012. Pengaruh Kebijakan Dividen, Kebijakan Hutang dan Profitabilitas terhadap Nilai Perusahaan Manufaktur yang terdaftar di Bursa Efek Indonesia Periode 2005-2010. Jurnal Riset Manajemen Sains Indonesia (JRMSI) Vol. 3 No. 1.

Mehta, Anupam. 2012. An empirical analysis of determinants of dividend policy evidence from the UAE companies. Global Review of Accounting and Finance, Vol 1, hal 1-48

Prasetyorini, Bhekti. Fitri. 2013. Pengaruh Ukuran Perusahaan, Leverage, Price Earning Ratio dan Profitabilitas terhadap Nilai Perusahaan. Jurnal IImu Manajemen. Vol 1 No. 1 Januari 2013.

Putri, R.M., Zahroh Z.A, dan Maria Goretti Wi Endang N.P. 2016. Pengaruh Rasio Likuiditas Dan Rasio Profitabilitas Terhadap Nilai Perusahaan. Jurnal Administrasi Bisnis. Vol 38 No.2 September.

Ristanti, Virghina., Topowijono., dan Sri Sulasmiyati. 2015. Pengaruh Likuiditas Dan Efisiensi Modal Kerja Terhadap Profitabilitas Perusahaan (Studi Pada Perusahaan Food And Beverages Yang Terdaftar Di BEI Tahun 2011 - 2013). Jurnal Administrasi Bisnis (JAB), Vol. 25 No. 1 Agustus.

Rodoni, A., dan Ali, H. 2014. Manajemen Keuangan Modern. Mitra Wacana Media. Jakarta

Safitri, O. N., Siti, R.H., dan Nila, F.N. 2014. The Influence Of Capital Structure And Profitability On Firm Value (A Study In Retail Companies Listed In Indonesia Stock Exchange 20102013 Period). Jurnal Administrasi Bisnis Vol. 13 No. 2 Agustus

Sartono, Agus. 2010. Manajemen Keuangan: Teori dan Aplikasi. Edisi 4. BPFEYogyakarta.Yogyakarta.

Shleifer, Andrei., dan R. W. Vishny. 1997. A Survey of Corporate Governance. The Journal of Finance Vol. LIL. No. 2, June

Sholihin, Mahfud dan Dwi Ratmono. 2013.Analisis SEM-PLS dengan WarpPLS 3.0. Andi Yogyakarta. Yogyakarta

Siagian, Ferdinand., Silvya V Siregar., dan Yan Rahadian. 2013. Corporate governance, reporting quality, and firm value: evidence from Indonesia. Journal of Accounting in Emerging Economie, Vol. 3 No. 1, pp. 4-20. 
Solimun., Adji Achmad Rinaldo Fernandes., Nurjannah. 2017.Metode Statistika Multivariat: Pemodelan Persamaan Struktural (SEM) Pendekatan WarpPLS. UB Press. Malang.

Sudiyatno, Bambang. 2010. Peran Kinerja Perusahaan Dalam Menentukan Pengaruh Faktor Fundamental Makroekonomi, Risiko Sistematis, dan Kebijakan Perusahaan Terhadap Nilai Perusahaan: Studi Empirik Pada Perusahaan Manufaktur Di Bursa Efek Indonesia. Disertasi. Universitas Diponegoro. Semarang.

Sudiyatno, Bambang., Ellen Puspitasari., dan Andi Kartika. 2012. The companys policy, firm performance and firm value: an empirical research on Indonesian stock ex- change. American International Journal of contemporary Research.

Tang, A. 2007. Simultaneous Approach To Analyzing The Relation Between Board Structure, Corporate Governance Mechanisms And Performance Of Japanese Firms (1989-2001). Theses. University of Saskatchewan. Saskatoon.

Wiyono, G., dan Hadri, K. 2017. Manajemen Keuangan Lanjutan : Berbasis Corporate Value Creation. UPP STIM YKPN. Yogyakarta. 